\title{
Litter can enhance pasture establishment on non-cultivable hill country
}

\author{
K.N. TOZER ${ }^{1}$, R.A. MOSS $^{2}$, C.A. CAMERON ${ }^{1}$, G.M. RENNIE ${ }^{1}$ and G.B. DOUGLAS ${ }^{3}$ \\ ${ }^{1}$ AgResearch Ruakura, Private Bag 3123, Hamilton 3214, New Zealand \\ ${ }^{2}$ AgResearch Lincoln, Private Bag 4749, Christchurch 8140, New Zealand \\ ${ }^{3}$ AgResearch Grasslands, Private Bag 11008, Palmerston North 4442, New Zealand \\ katherine.tozer@agresearch.co.nz
}

\begin{abstract}
The effect of litter (dead vegetation) on establishment of an autumn-sown grass-legume-herb mix was investigated in non-cultivable hill country in Waikato (2013) and in Canterbury $(2013,2014,2015)$. In Waikato, increasing litter height increased establishment of sown species by over 3 -fold when comparing establishment from herbicide-treated swards with $7 \mathrm{~cm}$ or $0 \mathrm{~cm}$ (bare ground) of litter (660 versus 190 seedlings $/ \mathrm{m}^{2}$ ). Only perennial ryegrass and white clover established of the seven oversown species in Waikato and none established in Canterbury. In Canterbury, soil surface temperatures were reduced and soil moisture was greater under $7 \mathrm{~cm}$ than $0 \mathrm{~cm}$ of litter, resulting in a $20 \%$ and $50 \%$ increase in average soil moisture content on the north and south aspects, respectively. It was concluded that litter enhanced establishment of perennial ryegrass and white clover in Waikato but the ameliorating effect of litter on the soil micro-climate was insufficient to enhance establishment in Canterbury.
\end{abstract}

Keywords: oversowing, pasture establishment, pasture species

\section{Key messages}

- Litter can enhance seedling establishment by over 3-fold

- The increased seedling establishment in Waikato most likely occurred because litter reduced the soil surface temperature and enabled more moisture to be retained in the top soil

- If drought conditions prevail and soil moisture is low, litter is unlikely to have a beneficial impact on seedling establishment.

\section{Introduction}

With land use intensifying there are greater demands for production from steep hill country, which comprises $40 \%$ of New Zealand's land surface below $1000 \mathrm{~m}$ (Blaschke et al. 1992). A national programme was developed to address this, with an objective focused on establishment of novel germplasm in non-cultivable hill country (Bray et al. 2013; Tozer et al. 2013).

Pasture establishment is difficult in these harsh environments. For example, 4 months after sowing, only $7 \%$ of aerially sown seed and $8 \%$ of hand sown seed established at Ballantrae in southern Hawke's Bay (Charlton 1977). In a review on aerial broadcasting of seed, Campbell (1992) reported similarly that establishment of viable seed ranged from 1 to $27 \%$ with a mean of $8 \%$. In a recent study with a site in each of four regions across New Zealand, seedling establishment ranged from 8 to $14 \%$, depending on the aspect, time of sowing, and seed mix sown (Tozer et al. 2013). Given the low ability of broadcast seed to produce seedlings (Awan et al. 1993), and low seedling survival, management strategies are required that enhance establishment of oversown seed in hill country.

The presence of a layer of litter (defined as 'procumbent stems, leaves, and inflorescences of plants, .... from the previous years' growth' (Evans \& Young 1970)) on the soil surface may increase establishment. For example, in a study on lowland, increasing the amount of herbicide-treated pasture cover from 850 (light cover) to $3500 \mathrm{~kg}$ dry matter (DM)/ha (heavy cover) increased establishment of oversown subterranean clover (Trifolium subterraneum) seed from $6 \%$ under light cover to $35 \%$ under heavy cover, and that of lucerne (Medicago sativa) from $4 \%$ to $22 \%$ (McWilliam \& Dowling 1970).

These benefits most likely occur through modifying the micro-climate. Litter can regulate soil temperatures and assist in retaining moisture; it has been suggested that "protective cover should be provided for all surface-sowings where moisture stress is likely to occur" (Campbell \& Swain 1973; Dowling et al. 1971). Evans \& Young (1970) found that litter absorbed and trapped radiation during the day and held the warm air on the soil surface during the night. Additionally, maximum temperatures at the soil surface were lower. Thus, litter moderated maximum and minimum seedbed temperatures, helped to maintain the soil-surface temperature above the critical level for germination, and delayed moisture depletion. In their study (Evans \& Young 1970), the daily minimum temperature was increased by up to $10^{\circ} \mathrm{C}$ and the maximum temperature decreased by $9^{\circ} \mathrm{C}$ over 4 weeks in spring in rangelands of Nevada, USA. Temperature regulation by vegetation 
was demonstrated on a fine winter's day at Whatawhata in the upper North Island, where soil temperatures at a $10 \mathrm{~mm}$ depth ranged from 3 to $20^{\circ} \mathrm{C}$ on steep northfacing slopes with negligible cover, while on camp sites with taller vegetation the temperature only ranged from 6 to $10^{\circ} \mathrm{C}$ (Ledgard et al. 1982).

There are few studies determining litter effects in hill country and no information was available on impacts of litter on the establishment of forage herbs. Accordingly, a field study was designed to determine the effect of three litter heights on establishment of a grass, legume and herb mix on north and south aspects in summer-dry North Canterbury and summermoist south Waikato. It was hypothesised that litter would enhance establishment, particularly at the drier Canterbury site.

\section{Methods}

Sites

The study was established on a commercial sheep and beef property at Ngaroma, South Waikato, with a 25 year average summer (December to February) rainfall of $236 \mathrm{~mm}$, and on a commercial sheep and beef property in Cheviot and Waipara in North Canterbury with equivalent rainfall of $127 \mathrm{~mm}$. All sites were on silt loam soils. The study was conducted over three successive years in Canterbury (Cheviot: 2013; Waipara: 2014-2015) and in 1 year in Waikato (2013).

At each of the sites, on slopes of $15-30^{\circ}$ on a north and south aspect, six treatments ( 3 litter heights $\mathrm{x} 2$ seed mixes (with versus without)), were arranged in four randomised complete blocks. Plots were $1 \mathrm{x} 1 \mathrm{~m}$ with new plots established and treatments applied each year in Canterbury.

Trials were fenced to exclude grazing livestock in both regions as well as for rabbits in Canterbury. In Canterbury, resident pasture was dominated by barley grass (Hordeum spp.), Vulpia spp. and browntop (Agrostis capillaris), and in Waikato by browntop and Yorkshire fog (Holcus lanatus). Perennial ryegrass (Lolium perenne), white clover (Trifolium repens) and subterranean clover ( $T$. subterraneum) were minor sward components.

\section{Treatments}

Plots were trimmed (using a STIHL FS110 brushcutter) to $7 \mathrm{~cm}$ height, harvested material was removed and Glyphosate 360 herbicide was applied in February at a rate of $1.98 \mathrm{~kg}$ a.i./ha to kill resident vegetation. Within 3 weeks of herbicide application, the vegetation within each plot was cut with a shearing hand piece to ground level ( $0 \mathrm{~cm}$, bare ground), $3 \mathrm{~cm}$ or $7 \mathrm{~cm}$ (uncut) to create the three litter treatments. Creating a litter layer using this method ensured that a uniform cover of litter was obtained. Harvested vegetation was removed, oven-dried $\left(24 \mathrm{~h}\right.$ at $\left.80^{\circ} \mathrm{C}\right)$ and weighed to estimate the litter biomass. The $3 \mathrm{~cm}$ litter height yielded means of 1-3 tonnes $\mathrm{DM} / \mathrm{ha}$ and the $7 \mathrm{~cm}$ treatment $4-8$ tonnes $\mathrm{DM} / \mathrm{ha}$, depending on the site, year and aspect.

The seed mix comprised perennial ryegrass (cv. Grasslands Samson infected with AR37 endophyte, sown at $11 \mathrm{~kg} / \mathrm{ha}$ ), cocksfoot (Dactylis glomerata cv. Grasslands Tekapo, 3), white clover (cv. Grasslands Bounty, 4), red clover (T. pratense cv. Grasslands Sensation, 6), subterranean clover (cv. Denmark, 6), plantain (Plantago lanceolata cv. Ceres Tonic, 1) and chicory (Cichorium intybus cv. Puna II, 1). All legume seed was inoculated with appropriate Rhizobium strains and all seeds were coated with an insecticide.

The seed mix was hand-broadcast in March, within 2-4 weeks of herbicide application depending on the site and year, and the back of a rake was used to apply firm pressure to the surface and enhance seed-soil contact. Slug bait was applied at a rate of $20 \mathrm{~g} / \mathrm{m}^{2}(15$ $\mathrm{g} / \mathrm{kg}$ Metaldehyde).

\section{Plant measurements}

Seedlings were counted at all sites approximately 10 weeks after sowing. In Canterbury, seedlings of sown species, unsown grasses and broadleaf weeds were counted in eight, $5 \mathrm{~cm}$ cores positioned at $20 \mathrm{~cm}$ intervals along two vertical transects in each plot. In Waikato, seedlings of sown species only were counted in situ in ten $5 \times 5 \mathrm{~cm}$ diameter quadrats using the same placement technique.

Botanical composition was assessed in Canterbury in the treatment plots in 2014 and 2015, approximately 6 months after sowing. All vegetation was harvested within a $50 \times 50 \mathrm{~cm}$ quadrat positioned centrally in each plot, and a subsample sorted into individual sown species, unsown grasses, and broadleaf weeds. All components and remainder were oven-dried $(24 \mathrm{~h}$ at $80^{\circ} \mathrm{C}$ ) to estimate the percentage DM content and DM/ ha of the components.

In the 2015 Canterbury trial, data were collected only from the north aspect; establishment on the south aspect was negligible.

\section{Average monthly rainfall}

Annual rainfall in Waikato in $2013(1387 \mathrm{~mm})$ and Canterbury in $2014(753 \mathrm{~mm})$ was below the longterm (1981-2010) average annual rainfall of 1577 $\mathrm{mm}$ (Waikato) and $829 \mathrm{~mm}$ (Canterbury), based on data from permanent weather stations within $10 \mathrm{~km}$ of the field sites. Annual rainfall in Canterbury in 2013 $(972 \mathrm{~mm})$ was above average although February was lower than average (Figure 1). Monthly rainfall in 2015 (Canterbury) was also lower than average for all months for which data were available (January-June). 


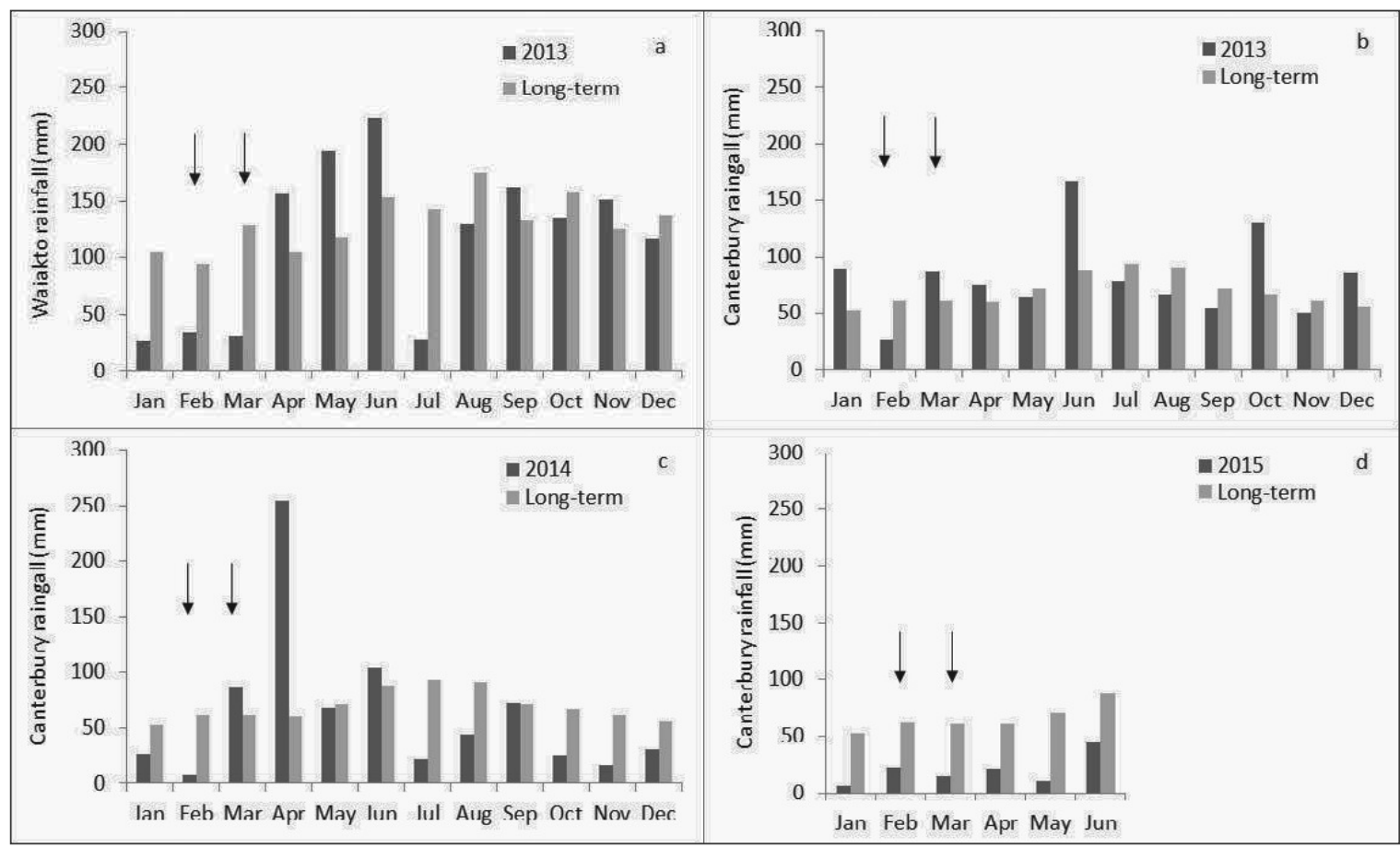

Figure 1 Long-term average rainfall (30-years, 1981-2010) and monthly rainfall for the a) Waikato and (b), (c) and (d) Canterbury field sites (based on data from the nearest weather stations that were within $10 \mathrm{~km}$ of each of the field sites). Arrows denote when herbicide was applied (February), and seed was hand-broadcast (March).

\section{Soil moisture and temperature}

Soil moisture was assessed in March and April at all sites. Two $2.5 \mathrm{~cm}$ diameter by $7.5 \mathrm{~cm}$ deep cores were removed from the periphery of each plot, and weighed before and after oven-drying $\left(24 \mathrm{~h}\right.$ at $\left.105^{\circ} \mathrm{C}\right)$ to determine the gravimetric moisture content $(\mathrm{m} / \mathrm{m} ; \%)$. Where necessary, irrigation was scheduled to increase the soil moisture content to $20 \%$. Irrigation was applied in Canterbury once in February (equivalent of $20 \mathrm{~mm}$ of rainfall) and March $(10 \mathrm{~mm})$ in 2013 and once in May $(30 \mathrm{~mm})$ in 2015. No irrigation was applied at the Waikato site.

Soil temperature was logged hourly $0.5 \mathrm{~cm}$ below the soil surface in each plot for one replicate on a north and south aspect in Canterbury in the 2013 and 2014 trials.

\section{Statistical analyses}

Data were subject to analysis of variance with seedling density data log-transformed where required to meet normality assumptions. Arithmetic means and SEDs are presented for all data but $\mathrm{P}$ values are from the logtransformed analysis.

\section{Results}

Waikato seedling establishment from oversown plots

Establishment of sown grasses, 99\% of which was perennial ryegrass, increased with increasing litter

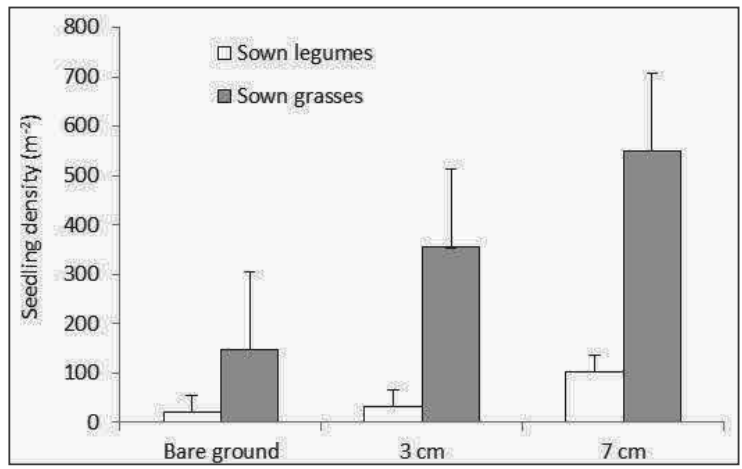

Figure 2 Mean seedling densities of sown legumes and sown grasses, from swards with $0 \mathrm{~cm}$ (bare ground), 3 or $7 \mathrm{~cm}$ of litter at the Waikato site, 10 weeks after sowing in 2013. Data were averaged over aspects. Standard error bars are shown.

height $(\mathrm{P}<0.01$, Figure 2). Establishment of total sown species also increased with litter height and was greater from under $7 \mathrm{~cm}$ than $0 \mathrm{~cm}$ of litter $(\mathrm{P}<0.01)$, resulting in 660 and 190 sown species seedlings $/ \mathrm{m}^{2}$, respectively. There was no significant difference between the three litter treatments in legume establishment, which averaged 50 seedlings $/ \mathrm{m}^{2}$ (Figure 2). Of the legume species sown, white clover comprised $60 \%$ of the legume present and red clover the remaining $40 \%$. Sown herb seedling establishment was negligible.

Approximately $60 \%$ of perennial ryegrass emergence 


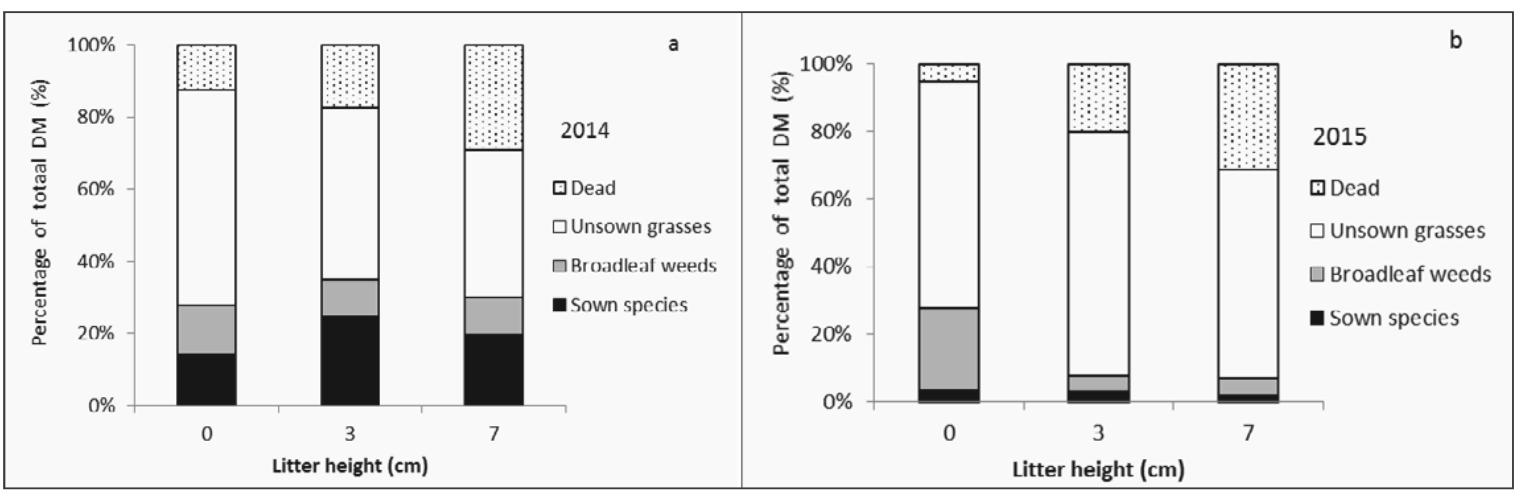

Figure 3 Percentage of total DM of dead vegetation, unsown grasses, broadleaf weeds and sown species 6 months after autumn sowing into herbicide-treated swards of different litter heights in Canterbury in each of 2 years ((a) 2014 and (b) 2015).

occurred from oversown seed and the remainder from the soil seedbank, based on a comparison of seedling density data from plots with and without oversown seed (not presented). Legumes emerged only in oversown plots.

Perennial ryegrass (530 vs 170 seedlings $/ \mathrm{m}^{2}$ ) and total sown species ( 580 vs 240 seedlings $/ \mathrm{m}^{2}$ ) emergence was 3.1- or 2.4-fold greater on the north than south aspect, respectively. There were no interactions between oversowing and litter treatment, or litter treatment and aspect.

Table 1 Establishment of sown grass and legume species, broadleaf weeds and unsown grasses from 0,3 and $7 \mathrm{~cm}$ litter height at the Canterbury field sites in each of 3 years. Data are averages over aspects in 2013 and 2014 and are from the north aspect only in 2015. ns $=\mathrm{P}>0.05$.

\begin{tabular}{lrrrrr}
\hline Plant densities $\left(\mathbf{m}^{2}\right)$ & \multicolumn{5}{c}{ Litter height (cm) } \\
\cline { 2 - 6 } & $\mathbf{0}$ & $\mathbf{3}$ & $\mathbf{7}$ & SED & F prob \\
\hline $\mathbf{2 0 1 3}$ & & & & & \\
Sown grass species & 80 & 120 & 60 & 50 & ns \\
Sown legume species & 240 & 80 & 50 & 132 & ns \\
Broadleaf weeds & 380 & 100 & 40 & 81 & 0.001 \\
Unsown grasses & 1130 & 2220 & 1360 & 262 & 0.006 \\
\hline 2014 & & & & & \\
Sown grass species & 330 & 380 & 330 & 194 & ns \\
Sown legume species & 290 & 290 & 220 & 134 & ns \\
Broadleaf weeds & 700 & 270 & 170 & 169 & 0.002 \\
Unsown grasses & 2310 & 2350 & 1140 & 394 & $<0.001$ \\
\hline 2015 & & & & & \\
Sown grass species & 0 & 30 & 0 & 15 & ns \\
Sown legume species & 160 & 110 & 160 & 79 & ns \\
Broadleaf weeds & 180 & 510 & 80 & 309 & ns \\
Unsown grasses & 3710 & 5000 & 4570 & 481 & ns \\
\hline & & & & &
\end{tabular}

\section{Canterbury seedling establishment from oversown plots}

Seedling densities of sown species were unaffected by oversowing in 2013, 2014 or 2015; 'sown species' (comprising only perennial ryegrass, white clover and subterranean clover) detected were those that had emerged from the soil seedbank and not from oversown seed.

The litter treatment had no effect on sown grasses, legumes and herbs or total sown species (Table 1), with total sown species averaging 210, 610 and 150 seedlings $/ \mathrm{m}^{2}$ in 2013, 2014 and 2015, respectively (averaged over all litter heights).

Broadleaf weed densities declined with increasing litter cover $(\mathrm{P}<0.01)$. Total unsown grass densities were lowest under $7 \mathrm{~cm}$ of litter $(\mathrm{P}<0.05)$ in 2014. There was no effect of litter on emergence in 2015.

In 2014, 6 months after sowing, there was no effect of the litter treatment on percentage DM in swards of sown grasses (averaging 9\%), sown legumes $(9 \%)$ or total sown species $(20 \%)$. Sown herb DM content was greater under $3 \mathrm{~cm}$ of litter (4\%) than $7 \mathrm{~cm}$ or $0 \mathrm{~cm}$ $(1 \%, \mathrm{P}<0.05)$. The percentage $\mathrm{DM}$ of unsown species decreased with increasing litter cover from $73 \%$ to $51 \%(\mathrm{P}<0.01)$ while that of dead vegetation increased from $13 \%$ to $29 \%(\mathrm{P}<0.001)$ for $0 \mathrm{~cm}$ and $7 \mathrm{~cm}$ of litter, respectively (Figure 3a). In 2015, there was also no effect of litter treatment on the percentage DM of sown species, which averaged 3\% (Figure 3b). Unsown species percentage DM declined from $92 \%$ to $67 \%$ and the percentage of dead vegetation increased from $5 \%$ to $32 \%$ when comparing emergence from $0 \mathrm{~cm}$ and 7 $\mathrm{cm}$ of litter, respectively $(\mathrm{P}<0.001)$. Percentage DM of unsown herbs was negligible $(<1 \%)$.

\section{Soil surface temperature and moisture}

Average temperatures, and temperature ranges, were generally lower with increasing litter cover on both aspects, with several exceptions. In 2014, average temperatures remained similar for the three litter 


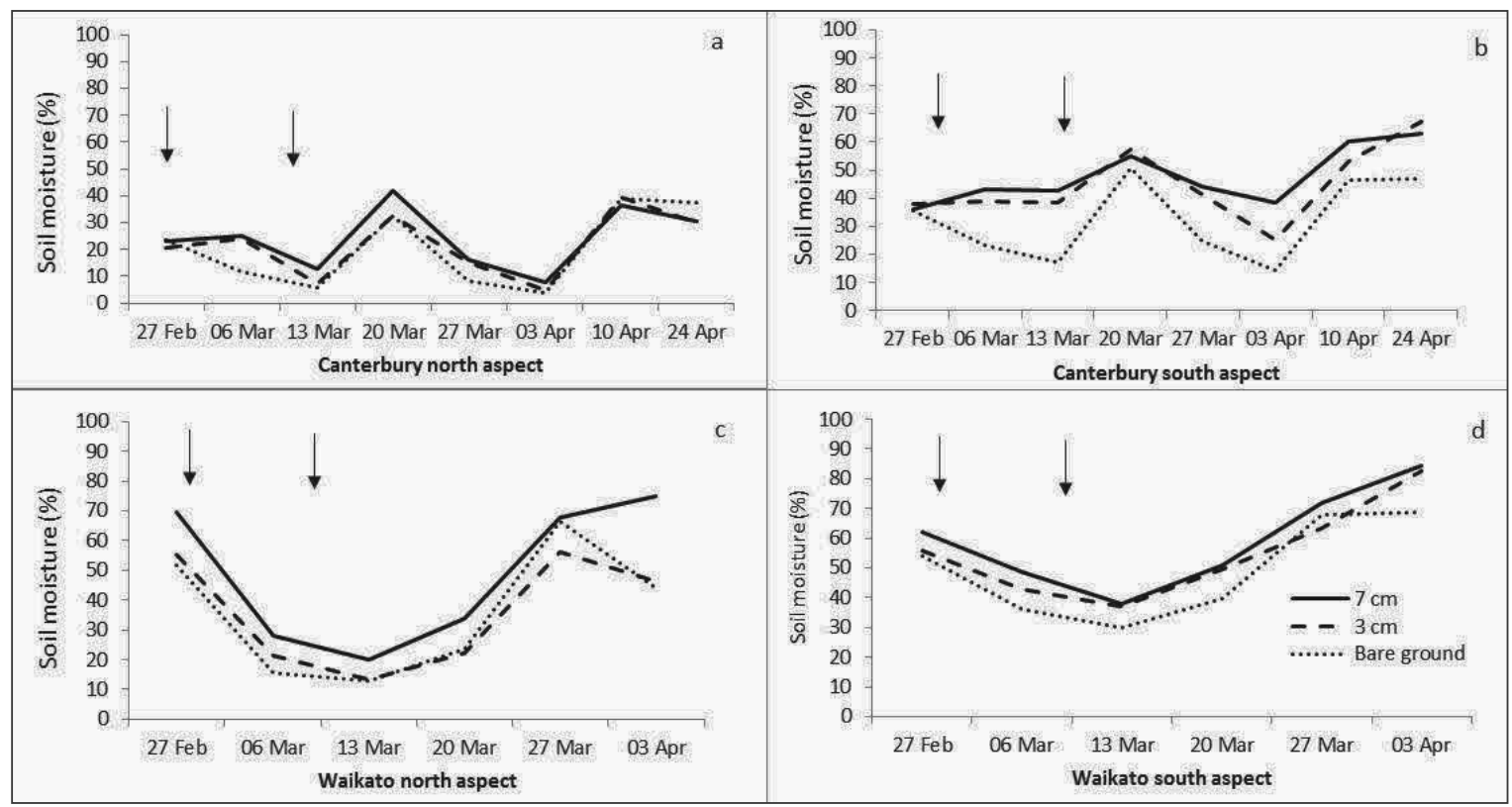

Figure 4 Gravimetric soil moisture content (\%) at 0-7.5 $\mathrm{cm}$ soil depth beneath 0 (bare ground), 3 and $7 \mathrm{~cm}$ of litter at the Canterbury (Figures 4a and b) and Waikato (Fig 4c and d) field sites in 2013. Arrows denote when herbicide was applied (February) and seed was hand-broadcast (March).

treatments on the south aspect, and on the north aspect, maximum temperatures under $3 \mathrm{~cm}$ of litter exceeded those under $0 \mathrm{~cm}$ of litter by up to 2 degrees in March and April (Table 2).

The soil moisture content was highest under $7 \mathrm{~cm}$ of litter, with the largest differences between treatments occurring on the south aspect in Canterbury (Figure 4). Soil moisture averaged 20, 22 and $24 \%$ on the north

Table 2 Soil surface temperature $\left({ }^{\circ} \mathrm{C}\right.$; mean (range)) at $0.5 \mathrm{~cm}$ depth on a north and south facing aspect beneath swards with 0 (bare ground), 3 and $7 \mathrm{~cm}$ of litter, at the Canterbury field site in 2013 and 2014. A dash indicates missing data due to logger malfunction (e.g. dislodged by birds, electronic issues).

Year Aspect Month

Litter height $(\mathrm{cm})$

\begin{tabular}{clccc} 
& & $\mathbf{0}$ & $\mathbf{3}$ & $\mathbf{7}$ \\
\hline 2013 North & March & $25(9-53)$ & $21(12-36)$ & $20(11-32)$ \\
& April & $19(7-41)$ & $17(11-29)$ & $16(10-29)$ \\
\hline \multirow{2}{*}{ So14 South } & March & $18(8-27)$ & $18(8-27)$ & $17(8-27)$ \\
& April & $12(5-22)$ & $12(6-20)$ & $12(6-19)$ \\
& May & $8(1-15)$ & $7(1-14)$ & $8(1-14)$ \\
& June & $6(1-11)$ & $6(1-11)$ & $6(1-11)$ \\
& March & $22(9-36)$ & $22(8-38)$ & - \\
& April & $16(7-38)$ & $15(7-39)$ & - \\
& May & $13(5-25)$ & $12(5-25)$ & - \\
& June & $11(6-19)$ & $11(6-17)$ & - \\
\hline
\end{tabular}

aspect, and 32,45 and $48 \%$ on the south aspect, for 0,3 and $7 \mathrm{~cm}$ of litter, respectively, in Canterbury. In Waikato soil moisture contents were higher, averaging 36,36 and $49 \%$ on the north aspect and 49,55 and $59 \%$ on the south aspect.

\section{Discussion}

Increasing litter cover increased the establishment of sown species in Waikato by over three-fold when comparing establishment from $7 \mathrm{~cm}$ of litter to that from $0 \mathrm{~cm}$, regardless of aspect. This may be due to greater soil moisture retention with increasing litter cover on both the north and south aspects as occurred in this study, and has been reported elsewhere (Evans \& Young 1970). Increasing litter height increases soil surface shading and reduces desiccation in the top few centimetres of soil where establishing seedlings with small, shallow root systems are particularly vulnerable to dehydration (Fenner 1987).

In contrast, there was no evidence that oversown seed established in any of the treatments on either the north or south aspect in Canterbury in any year, based on a comparison of data from sown and unsown plots. Given the failure of oversown seed to establish, sown species present were predominantly those that had emerged from the soil seedbank. These were perennial ryegrass, white clover (comprising up to one third of sown legumes) and subterranean clover (comprising up to $100 \%$ of sown legumes).

There may be several reasons why oversown seed in Canterbury did not produce seedlings. Firstly, oversown 
germplasm was less well adapted to the environment than resident germplasm (Wedderburn \& Pengelly 1991), secondly, seed-soil contact of oversown seed was low despite the raking and compacting of soil and thirdly, moisture stress reduced germination, emergence or survival. The lack of establishment was most likely due to moisture stress that occurred in each of the 3 years, especially in the top soil. Soil surface moisture is particularly important for seed germination and emergence (Awan et al. 1996), and moisture levels at the surface would presumably be even lower than those found in the top soil (Figure 1). In 2013, soil moisture fell as low as $4 \%$ under $0 \mathrm{~cm}$ litter and $8 \%$ under 7 $\mathrm{cm}$ litter on the north face, and maximum temperatures reached $53{ }^{\circ} \mathrm{C}$ under $0 \mathrm{~cm}$ litter and $32^{\circ} \mathrm{C}$ under $7 \mathrm{~cm}$ of litter. Rainfall during February and March was much lower than the long-term average in 2013 in Waikato and 2015 in Canterbury. While temperature extremes were lower and more moisture was retained in the top soil on the south than north aspect, results infer that it was inadequate for establishment of oversown seed. In dry conditions, there is also a risk that litter may prevent rainfall from reaching the root zone of the establishing seedlings. The unsown species that emerged from the seedbank (e.g. up to $97 \%$ of total seedling emergence in Canterbury 2015) would also be competing against seedlings of the sown species impeding their establishment.

Of the oversown species, only perennial ryegrass, white clover and red clover established in numbers sufficient to be analysed - and only in Waikato. Some litter cover may be particularly advantageous for legumes, which are more vulnerable to moisture stress than grasses due to thicker roots that penetrate the soil more slowly (Campbell \& Swain 1973).

There was little evidence of forage herb establishment at either site. Data from Table 1 suggest that establishment of broadleaf species may be impeded by litter but given that the forage herbs did not establish even when oversown on bare ground $(0 \mathrm{~cm}$ litter $)$, effects of litter on forage herb establishment cannot be verified. Results are in contrast to Tozer et al. (2013) where broadcast forage herbs included in a grass, legume and herb mix, established on north and south aspects from spring and autumn sowings.

Litter had an impact on emergence of unsown species in Canterbury. There was a significant decline in broadleaf weeds with increasing litter cover in the 2013 and 2014 trials. Consequently, litter may be useful in reducing the abundance of broadleaf weeds such as thistles when establishing new hill country pastures. Under litter, the light requirements for germinating thistle seeds and growing seedlings may not be met. Further, the horizontal leaves of broadleaf seedlings would make penetration of the litter layer difficult.
Reduced seedling abundance with increasing litter is consistent with a review on thistles by Bourdôt (1996) in which thistle emergence was greater from bare ground than from undisturbed pasture. In contrast, the vertical seedling leaves of grasses could more easily penetrate a litter layer. This is consistent with the Canterbury data in this study showing unsown grasses established well from under a layer of litter. However, there was negligible thistle emergence from the unsown plots, so the effects of litter on thistles in this study could not be ascertained.

In conclusion, litter can enhance the establishment of oversown perennial ryegrass and white clover. This effect of litter is most likely achieved by reducing soil surface temperatures and retaining moisture in the top soil. Under severe drought conditions, the ameliorating effect of litter on the soil micro-environment is not likely to have a positive impact and may prevent rainfall from reaching the soil surface. Adjusting grazing management to ensure some litter cover is present before sowing (e.g. $3 \mathrm{~cm}$ ) may improve establishment given adequate soil moisture.

\section{ACKNOWLEDGEMENTS}

Funding from Ministry of Business, Innovation and Employment, DairyNZ, Fonterra, Beef + Lamb New Zealand and DCANZ (Dairy Companies Association of New Zealand); advice on farmer needs from Beef + Lamb New Zealand; the managers and staff on whose properties the studies were conducted at Ngaroma, Cheviot and Waipara. Thanks also to Trevor Knight and Natalie Mapp for assistance with data collection and David Hume for helpful comments on the manuscript.

\section{REFERENCES}

Awan, M.H.; Barker, D.J.; Kemp, P.D.; Choudhary, M.A. 1996. Soil surface moisture measurement and its influence on the establishment of three oversown legume species. The Journal of Agricultural Science 127: 169-174.

Awan, M.H.; Kemp, P.D.; Choudhary, M.A.; Barker, D.J. 1993. Pasture legume establishment from oversowing in drought-prone hill country. Proceedings of the New Zealand Grassland Association 55: 101-104.

Blaschke, P.M.; Trustrum, N.A.; DeRose, R.C. 1992. Ecosystem processes and sustainable land use in New Zealand steeplands. Agriculture, Ecosystems and Environment 41: 153-178.

Bourdôt, G.W. 1996. Interference between pasture plants and thistles - a review. Plant Protection Quarterly 11: 265-270.

Bray, A.R.; Fraser, T.J.; King, W.M.; Mackay, A.D.; Moot, D.J.; Stevens, D.R. 2013. Pasture improvement needs and options for New Zealand sheep and beef farms. pp. 844-845. In: Proceedings of the 22nd 
International Grassland Congress. Eds. Michalk, D.L.; Millar, G.D.; Badgery, W.B.; Broadfoot, K.M. New South Wales Department of Primary Industry, Sydney, Australia.

Campbell, B.D. 1992. Extending the frontiers of aerially sown pastures in temperate Australia: a review. Australian Journal of Experimental Agriculture 32: 127-148.

Campbell, M.H.; Swain, F.G. 1973. Effect of strength, tilth and heterogeneity of the soil surface on radicleentry of surface-sown seeds. Grass and Forage Science 28: 41-50.

Charlton, J.F.L. 1977. Establishment of pasture legumes in North Island hill country. Part 2 Seedling establishment and plant survival. New Zealand Journal of Experimental Agriculture 5: 385-390.

Dowling, P.M.; Clements, R.J.; McWilliam, J.R. 1971. Establishment and survival of pasture species from seed sown on the soil surface. Australian Journal of Agricultural Research 22: 61-74.

Evans, R.A.; Young, J.A. 1970. Plant litter and establishment of alien annual weed species in rangeland communities. Weed Science 18: 697-703.
Fenner, M. 1987. Seedlings New Phytologist 106: 35-47.

Ledgard, S.F.; Sheath, G.W.; Gillingham, A.G. 1982. Influence of some soil and pasture components on the growth of hill country pastures. 1. Winter and spring production. New Zealand Journal of Experimental Agriculture 10: 239-244.

McWilliam, J.R.; Dowling, P.M. 1970. Factors affecting the germination and establishment of pasture seed on the soil surface. pp. 578-583. In: Proceedings of the XI International Grasslands Congress. Ed. Norman, M. J. T. St Lucia: University of Queensland Press, Harlington, Queensland, Surfers Paradise, Australia.

Tozer, K.N.; Douglas, G.B.; Cameron, C.A.; Fraser, T.J.; Moss, R.A.; Rennie, G.M.; Knight, T.L.; Muir, P.D. 2013. Pasture establishment on non-cultivable hill country. Proceedings of the New Zealand Grassland Association 75: 215-220.

Wedderburn, M.E.; Pengelly, W.J. 1991. Resident ryegrass in hill country pastures. Proceedings of the New Zealand Grassland Association 53: 91-95. 
